\title{
IAMJ
}

INTERNATIONAL

AYURVEDIC

MEDICAL JOURNAL

Research Article

ISSN: 2320-5091

Impact Factor: 6.719

\section{A CLINICAL STUDY TO EVALUATE THE EFFICACY OF JATYADI GHRITA VIKESHIKA DRESSING IN THE MANAGEMENT OF DUSHTAVRANA W.S.R. TO VENOUS ULCER}

\author{
Bhagyashree Parameshwar Hegde ${ }^{1}$, Syeda Ather Fathima ${ }^{2}$, Geetanjali Hiremath ${ }^{3}$, \\ Shivalingappa J Arakeri ${ }^{4}$, Mohasin Kadegaon ${ }^{5}$
}

${ }^{1}$ PG Scholar, Department of Shalyatantra, Taranath Government Ayurvedic Medical College, Ballari, Karnataka, India

${ }^{2}$ Principal, Taranath Government Ayurvedic Medical College, Ballari, Karnataka, India

${ }^{3}$ Assistant professor Department of Shalyatantra, Taranath Government Ayurvedic Medical College, Ballari,

Karnataka, India

${ }^{4}$ Assistant professor Department of Shalyatantra, Taranath Government Ayurvedic Medical College, Ballari,

Karnataka, India

${ }^{5}$ Associate professor \& HOD, Department of Shalyatantra, Taranath Government Ayurvedic Medical College,

Ballari, Karnataka, India

Corresponding Author: bhagyashreehegde14@gmail.com

\section{https://doi.org/10.46607/iamj05p6012021}

(Published online: November 2021)

Open Access

(C) International Ayurvedic Medical Journal, India 2021

Article Received: 21/09/2021 - Peer Reviewed: 19/11/2021 - Accepted for Publication: 27/11/2021

Check for updates

\section{ABSTRACT}

Venous ulcers are a frequently encountered problem in the present era produced commonly as a complication of varicose veins and it causes long-term agony to the patient. The properties of a venous ulcer-like non-healing nature, severe discharge pain itching etc. come under the umbrella of Dushtavrana explained by Acharya Sushruta. Management of chronic venous ulcers is a challenging one. Commonly practised gauze dressing for chronic ulcers may be disruptive for wound healing as it gets adhered to wound bed hampering breathing of wound and causing damage to granulation tissue during its removal. These factors may be responsible for delayed wound healing. In modern science, there are plenty of sterilized, packed dressing materials available in the market. But nowhere 
Ayurvedic ready to use dressing material is manufactured or made available in the market. Keeping these into consideration, Jatyadi Ghrita Vikeshika i.e., the cloth containing Jatyadi Ghrita is prepared, packed and sterilized. This is compared with the Sofra-tulle of modern science. In the present comparative study, 40 patients were selected and divided into 2 groups of 20 patients each and trial group patients were treated with Jathyadi Ghrita Vikeshika dressing \& control group patients were treated with Sofra-tulle dressing for 28 days. The study revealed highly significant results in both groups statistically.

On observation except for pain, in all other parameters, Jatyadi Ghrita Vikeshika was found more effective. Hence Jatyadi Ghrita Vikeshika can be undoubtedly used in Dushtavrana which promotes both Shodhana (Cleansing) and Ropana (Healing)of Vrana.

Keywords: Dushtavrana, Venous Ulcer, Jatyadi Ghrita Vikeshika, Sofra-Tulle dressing.

\section{INTRODUCTION}

As the French Barber surgeon Ambroise Pere rightly quoted, "I dressed him and God healed him" (1), wound healing is a natural process and all the treatments which we do are just to hasten its phase. From the era of Hippocrates where wine and vinegar were the chief wound healers, wound treatment has undergone great advancements and become an area of the quest for researchers.

Since the times of Vedas one can find the references for Vrana Chikitsa which indicates wound management was not new to the Indians. Shalyatantra one among Ashtangas of Ayurveda mainly emphasizes Vrana. Acharya Sushruta defines Vrana as, that which covers the body part and leaves its scar even after healing till the last breath of the individual. (2) The features of Dushtavrana mentioned can be compared with chronic non-healing ulcers in modern science.

In modern science, ulcer refers to discontinuity in the covering epithelium, skin or mucous membrane and may either follow molecular death of surface epithelium or its traumatic removal. ${ }^{(3)}$ Among ulcers, venous ulcer constitutes $81 \%$ of leg ulcers. Surgical treatments available are unaffordable with a poor prognosis and high recurrence rate.

In the conservative management of modern science, there are plenty of dressing materials available for ulcers. Among them Sofra-tulle containing 1\% Framacytein Sulphate, Soft Paraffin, Anhydrous lanolin is used as dressing material in potentially infected ulcers and burns. They are designed to re- duce adherence at the wound bed and to allow exudates to pass into the secondary dressing, thus maintaining a moist wound bed which is very essential for early wound healing. ${ }^{(4)}$

The properties of a venous ulcer-like non-healing nature, severe discharge pain itching etc. come under the umbrella of Dushtavrana explained by Acharya Sushruta. Hence among Shashti upakramas an apt choice of treatment serves the purpose. Jatyadi Ghrita is widely used as Vrana Shodhaka and Ropa$k a$ and used in Marmashrita Vrana (Ulcer in Vital Point), Kledayukta vrana (Moist wound), Sookshma Mukayukta vrana (Ulcer with small opening), Gambhira rujayukta Vrana (Deep-seated Painful ulcer).

(5) Studies have found that Jatyadi Ghrita promotes early wound contraction and re-epithelialisation of wounds and has got anti-inflammatory effect ${ }^{(6)}$.

Acharya Sushruta also mentions Bandha (Bandage) for healing purpose ${ }^{\mathrm{s}}{ }^{(7)}$ in different forms like Vikeshika, Kavalika, Plota, Pichu. ${ }^{\left({ }^{8}\right)}$ Among these Vikeshika is the cloth which contains Tila kalka Madhu and Ghrita. ${ }^{(9)}$ But clinically usage of these bandaging materials is very limited. Commonly practised gauze dressing may be disruptive for wound healing as it gets adhered to the wound bed hampering the breathing of the wound and causing damage to granulation tissue during its removal. These factors may be responsible for delayed wound healing. Also adopting the rules of Vikeshika Oushadha mentioned by Acharya Sushruta while doing conventional dressing may not be possible all the time. In modern 
science, there are plenty of sterilized, packed dressing materials available in the market. But nowhere Ayurvedic ready to use dressing material is manufactured or made available in the market. Hence adopting good advancements from other science without altering the basic principle is always acceptable. Upgradation and Standardization of dressing methodology like the quality of gauze material, size of dressing material which respects the wound healing is need of the hour.

Keeping these into consideration, Jatyadi Ghrita Vikeshika using leno weave non-absorbent gauze impregnated with Jatyadi Ghrita with standard size has been prepared, sterilized and sealed in a pack which is an innovative contribution in Ayurvedic method of dressing. So, in this study, a unique at- tempt has been made to compare the results of Jatyadi Ghrita Vikeshika and Sofra tulle Dressing in the management of Dushtavrana w.s.r. to Venous Ulcer.

OBJECTIVES OF THE STUDY: To compare the efficacy of Jatyadi Ghrita Vikeshika and Sofratulle dressing in the management of Dushta vrana with special reference to Venous ulcer.

\section{MATERIALS \& METHODS:}

Drug Source: Required raw materials for Jatyadi ghrita were collected from GMP certified company. Necessary processing of raw materials and preparation of Jatyadi Ghrita done in the Postgraduate Dept. of Rasashastra and Bhaishajya Kalpana, Taranath Govt. Ayurvedic Medical College, Ballari.

\section{Drug Preparation:}

\begin{tabular}{|l|l|}
\hline Jatipatra & $1 / 4^{\text {th }}$ part \\
\hline Nimbapatra & $1 / 4^{\text {th }}$ part \\
\hline Patolapatra & $1 / 4^{\text {th }}$ part \\
\hline Katuka & $1 / 4^{\text {th }}$ part \\
\hline Darvi & $1 / 4^{\text {th }}$ part \\
\hline Nisha & $1 / 4^{\text {th }}$ part \\
\hline Sariva & $1 / 4^{\text {th }}$ part \\
\hline Manjishta & $1 / 4^{\text {th }}$ part \\
\hline Ushira & $1 / 4^{\text {th }}$ part \\
\hline Sikta & $1 / 4^{\text {th }}$ Part \\
\hline ShuddhaTuthha & $1 / 4^{\text {th }}$ part \\
\hline Madhuka & $1 / 4^{\text {th }}$ part \\
\hline Karanjabeeja & $1 / 4^{\text {th }}$ part \\
\hline Ghrita & 4 parts \\
\hline Jala & 16 parts \\
\hline
\end{tabular}

Jatyadi Ghrita was prepared as per the classical reference of Ghrita paka kalpana

\section{Preparation of Jatyadi Ghrita Vikeshika}

1. Sterile clean leno-weave fabric gauze of $10 \times 10 \mathrm{~cm}$ size was taken.

2. It was impregnated with Jatyadi Ghrita uniformly

3. Thus prepared Vikeshika will be kept in between layers of silver foil and butter paper in order to prevent leakage of Ghrita.

4. Then it is kept inside a silver foil pouch, sealed and labelled. Stored in cool temperature. Labelling was done which contains material used, a medicine used with its manufactured date, expiry date and storage. 


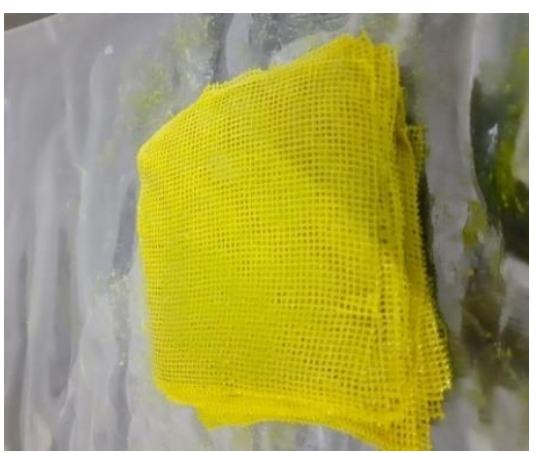

\section{Jatyadi Ghrita impregnated} vikeshika

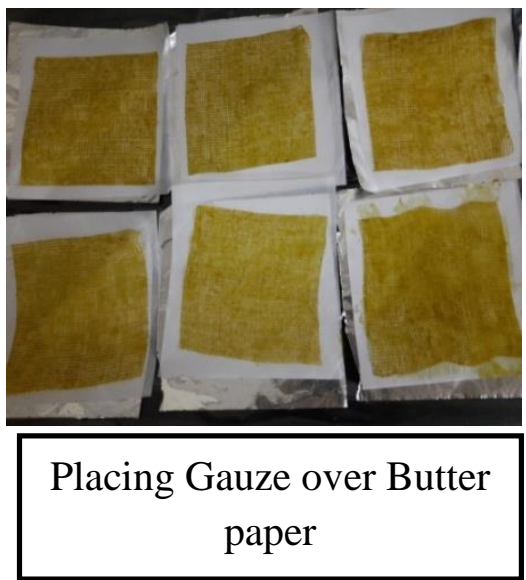

Clinical Source: A Total of 40 patients who fulfilled the inclusion criteria, of either sex attending the OPD and IPD of Shalya Tantra, Taranath Government Ayurvedic Medical College and Hospital, Ballari were randomly selected for the study.

Intervention: Venous ulcer cleaned with Normal saline in both groups. Jathyadi Ghrita Vikeshika dressing done in Group A \& Sofra-tulle dressing done in Group B.

The dressing was done for 28 days, and observations were noted on the $7^{\text {th }}, 14^{\text {th }}, 21^{\text {st }}, 28^{\text {th }}$ day and follow up after 1 week.
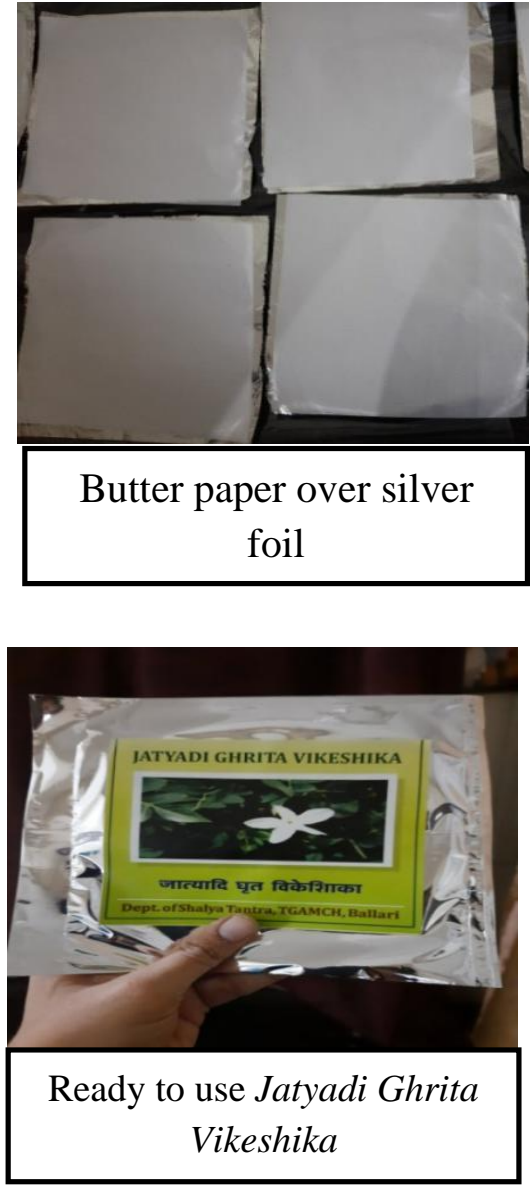

Table 1: Subjective Parameters

\begin{tabular}{|l|l|l|l|l|}
\hline Grade & Pain & Itching & Foul smell & Swelling \\
\hline 0 & No pain & Absent & Absent & Absent \\
\hline 1 & Mild pain (no need of analgesics) & Present & Present & Present \\
\hline 2 & Moderate pain (subsides with analgesics) & & & \\
\hline 3 & Severe pain (persists with analgesics) & & & \\
\hline
\end{tabular}


Table 2: Objective Parameters

\begin{tabular}{|l|l|l|l|l|}
\hline Grade & Border & Floor & Discharge & Size \\
\hline 0 & well defined & Wound healed & No discharge & Wound healed \\
\hline 1 & $\begin{array}{l}\text { With an advanced border of } \\
\text { epithelium }\end{array}$ & $\begin{array}{l}\text { Evenly spread pink granulation tis- } \\
\text { sue }\end{array}$ & $\begin{array}{l}\text { Mild discharge (wets 2x2 cm } \\
\text { gauze piece/day) }\end{array}$ & $0-5 \mathrm{~cm}$ \\
\hline 2 & $\begin{array}{l}\text { No advancing border of } \\
\text { epithelium }\end{array}$ & $\begin{array}{l}\text { Evenly spread beefy } \\
\text { granulation tissue }\end{array}$ & $\begin{array}{l}\text { Moderate discharge (wets 2x2 } \\
\text { cm 2 gauzes per day) }\end{array}$ & $5-10 \mathrm{~cm}$ \\
\hline 3 & Not Well defined & $\begin{array}{l}\text { No healthy granulation tissue or } \\
\text { covered with slough }\end{array}$ & $\begin{array}{l}\text { Severe discharge (wets 2x2 } \\
\mathrm{cm}>2 \text { gauzes per day. }\end{array}$ & $10-15 \mathrm{~cm}$ \\
\hline 4 & - & - & - & $>15 \mathrm{~cm}$ \\
\hline
\end{tabular}

OBSERVATIONS: The present study revealed that incidence of dushta vrana was more common in 41 50 years i. e $32.5 \%$. Maximum patients were male i.e., $90 \%$. $57.5 \%$ of workers were moderate workers. $45 \%$ of patients were having a history of varicose veins rest $55 \%$ did not have varicose veins. $77.5 \%$ had 3 years of ulcer history. $67.5 \%$ of venous ulcers were in the left lower limb and specifically, $27.5 \%$ were in the medial aspect.47.5\% of ulcers had an oval shape. $45 \%$ of patients had no advancing border of epithelium in ulcer margin. $60 \%$ of ulcers had slough in the floor. $40 \%$ of ulcers had a mild discharge.

RESULTS: The assessment parameters like Pain, Size, Margin, Floor \& discharge were subjected to Wilcoxon Signed Rank Test to compare the mean rank within the group and the Mann Whitney $\mathbf{U}$ test to compare the Mean Rank difference Values between the groups \& draw the conclusion. The assessment parameters like Itching, Foul smell, Swelling were subjected to McNemar's test within the group and Fisher's exact test between the groups.

Table 3: Effect of Treatments on assessment parameters in Group A:

\begin{tabular}{|l|l|l|l|l|l|l|l|}
\hline Group A & BT & AT & $\mathbf{\%}$ & S. D & WSRT Value & Z-Value & P-Value \\
\hline Pain & 1.3 & 0.4 & 69.23 & 0.718 & -138.00 & -3.499 & $<0.001$ \\
\hline Itching & 0.85 & 0 & 100 & -- & -- & -- & $<0.001$ \\
\hline Foul smell & 0.35 & 0.05 & 95 & -- & -- & -- & $<0.031$ \\
\hline Size & 1.3 & 0.65 & 50 & 0.489 & -91.00 & -3.606 & $<0.001$ \\
\hline Swelling & 0.35 & 0 & 100 & -- & -- & -- & $<0.01$ \\
\hline Margin & 2.1 & 0.55 & 73.80 & 0.826 & -153.00 & -3.782 & $<0.001$ \\
\hline Floor & 2.45 & 0.65 & 73.46 & 1.152 & -136.00 & -3.573 & $<0.001$ \\
\hline Discharge & 1.9 & 0.7 & 63.15 & 1.105 & -105.00 & -3.376 & $<0.001$ \\
\hline
\end{tabular}

Table 4: Effect of Treatments on assessment parameters in Group B:

\begin{tabular}{|l|l|l|l|l|l|l|l|}
\hline Group B & BT & AT & $\mathbf{\%}$ & S. D & WSRT Value & Z-Value & P-Value \\
\hline Pain & 1.1 & 0.15 & 86.36 & 0.510 & -153.00 & -3.945 & $<0.001$ \\
\hline Itching & 0.85 & 0 & 100 & -- & -- & - & $<0.001$ \\
\hline Foul smell & 0.35 & 0.05 & 95 & -- & -- & - & $<0.004$ \\
\hline Size & 1.35 & 0.9 & 33.33 & 0.510 & -45.00 & -3.00 & $<0.004$ \\
\hline Swelling & 0.35 & 0 & 100 & & - & - & $<0.125$ \\
\hline Margin & 2.5 & 1.00 & 60 & 0.761 & -190.00 & -3.912 & $<0.001$ \\
\hline Floor & 2.5 & 1.15 & 54 & 1.040 & -160.00 & -3.565 & $<0.001$ \\
\hline Discharge & 1.85 & 1.10 & 40.54 & 0.550 & -105.00 & -3.638 & $<0.001$ \\
\hline
\end{tabular}


Table 5: Comparative Effect of treatment on Pain in-between group A and Group B

\begin{tabular}{|l|l|l|l|l|l|}
\hline PARAMETER & GROUP A & GROUP B & T- VALUE & P-VALUE & REMARKS \\
\hline Pain & 1.000 & 1.000 & 418.500 & 0.782 & N. S \\
\hline Size & 1.000 & 0.000 & 450.000 & 0.215 & N. S \\
\hline Margin & 2.000 & 1.000 & 428.500 & 0.597 & N. S \\
\hline Floor & 2.000 & 1.000 & 451.500 & 0.249 & N. S \\
\hline Discharge & 1.000 & 1.000 & 454.000 & 0.199 & N. S \\
\hline
\end{tabular}

Table 6: Effect of Treatment

\begin{tabular}{|l|l|l|l|}
\hline Class & Grading & No of patients in Group A & No of patients in Group B \\
\hline $0-25 \%$ & Poor Response & 0 & 0 \\
\hline $26 \%-50 \%$ & Mild Response & 4 & 4 \\
\hline $51 \%-75 \%$ & Moderate Response & 6 & 9 \\
\hline $76 \%-100 \%$ & Marked Response & 10 & 7 \\
\hline
\end{tabular}

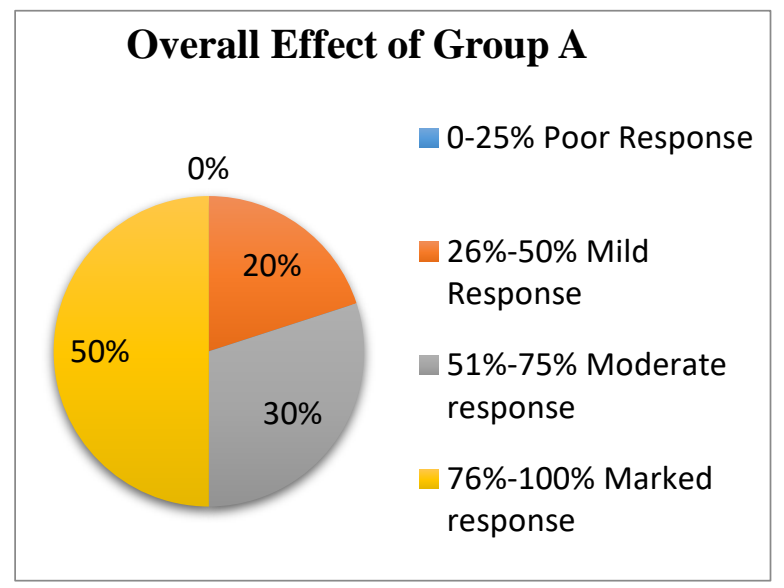

Graph 1: Results on Group A

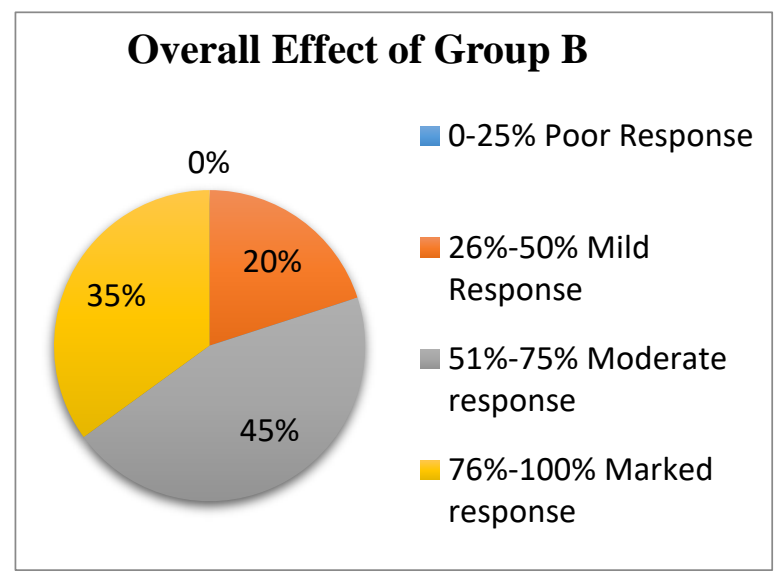

Graph 2: Results on Group B

Figure 1-3: Showing result in Group A
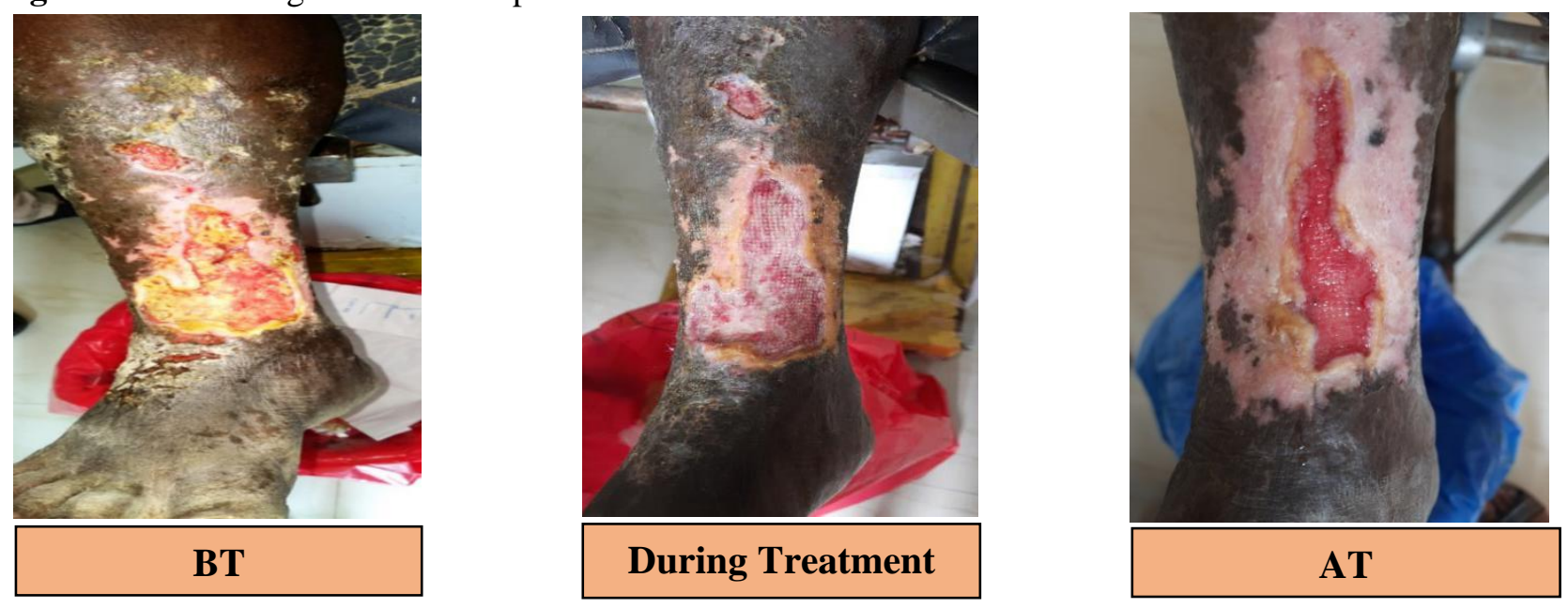
Figure 4-6: Showing result in Group B

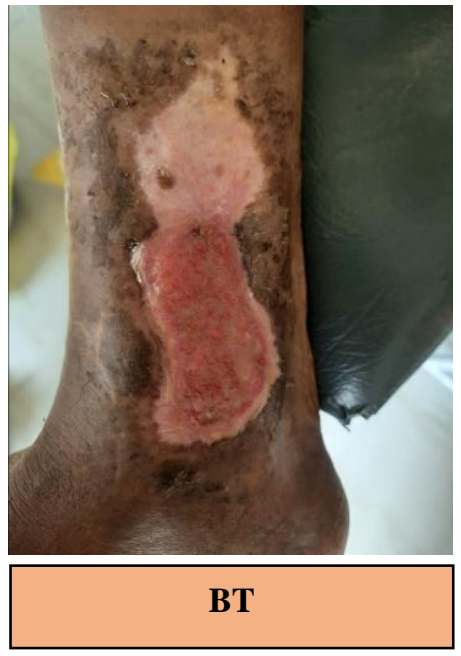

\section{DISCUSSION}

The ability of an organism to repair or regenerate tissue is a definite advantage for surviving. Wound healing is a complex mechanism that includes highly organized cellular, humoral and molecular mechanisms. Any interruption in this natural process will end up in abnormal wound healing. In modern science, chronic non-healing ulcers like venous ulcers are a challenge to treat. In the Chikitsa of Vrana, Acharya Sushruta explains 60 Upakramas

\section{Effect of therapies on Dushtavrana:}

Effect on Pain: Sofra tulle dressing has a better effect than Jatyadi Ghrita VSikeshika dressing in terms of pain. It may be because of the bactericidal effect of framycetin which helped in the reduction of infection.

Effect on Margin: Jatyadi Ghrita Vikeshika dressing had a better effect than Sofra tulle dressing in terms of margin. It may be because studies have shown that Jatyadi Ghrita promotes early epithelialization.

Effect on Floor: Jatyadi Ghrita Vikeshika dressing had a better effect than Sofra tulle dressing in terms of the floor. It may be because of anti-microbial and autolytic debridement of linoleic acid present in Jatyadi ghrita which promotes clears off slough \& promotes the growth of granulation tissue formation.

Effect on Discharge: Jatyadi Ghrita Vikeshika dressing had a better effect than Sofra tulle dressing in terms of reducing discharge. It may be because of Rooksha guna of Tikta, katu, Kashaya rasa \& Ushna veerya of ingredients of Jatyadi Ghrita that reduces the Srava occurred due to Kapha dosha.

Discussion on the mode of action of drug:

Jatyadi Ghrita mentioned by Acharya Vagbhata has both Shodhana and Ropana properties.

Sorfratulle is an antibiotic tulle dressing used for potentially infected ulcers and burns. 
Flow-chart: Mode of action according to Ayurveda

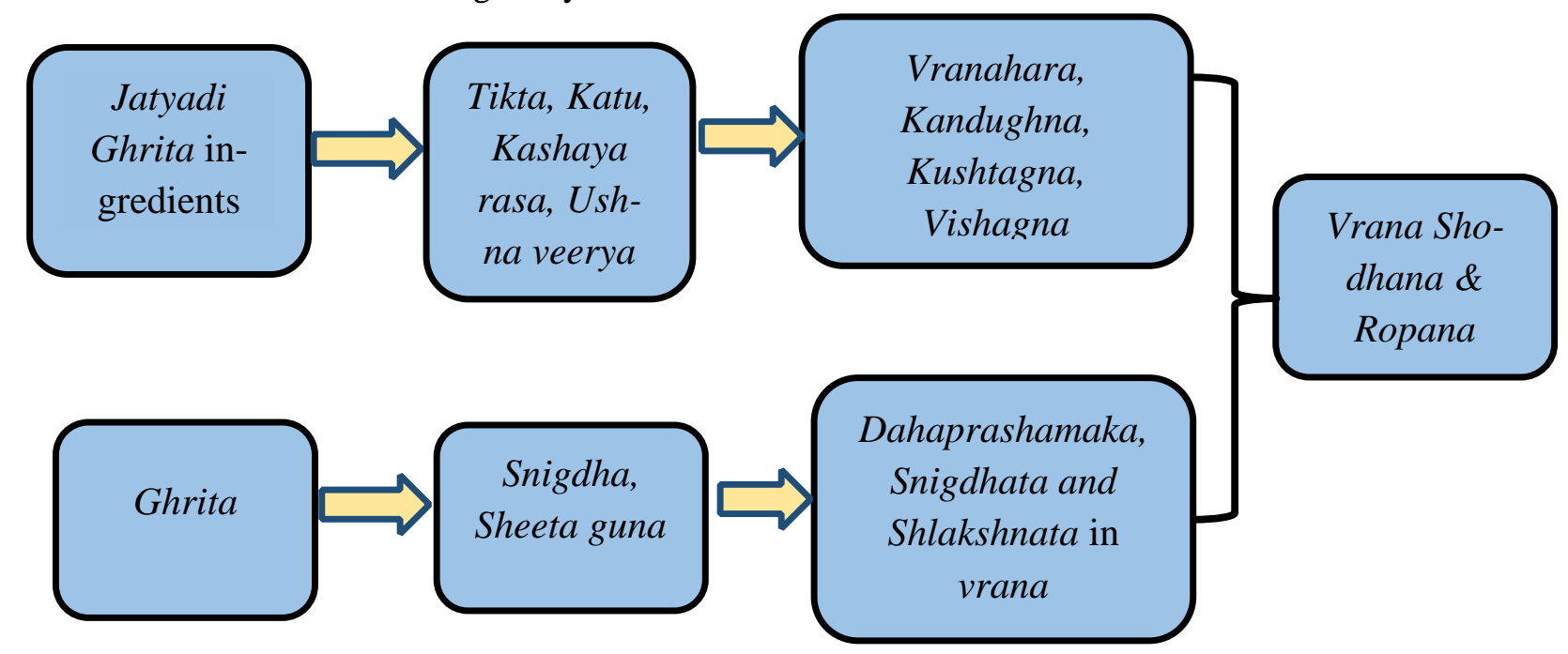

Flow-chart: Mode of action according to Modern

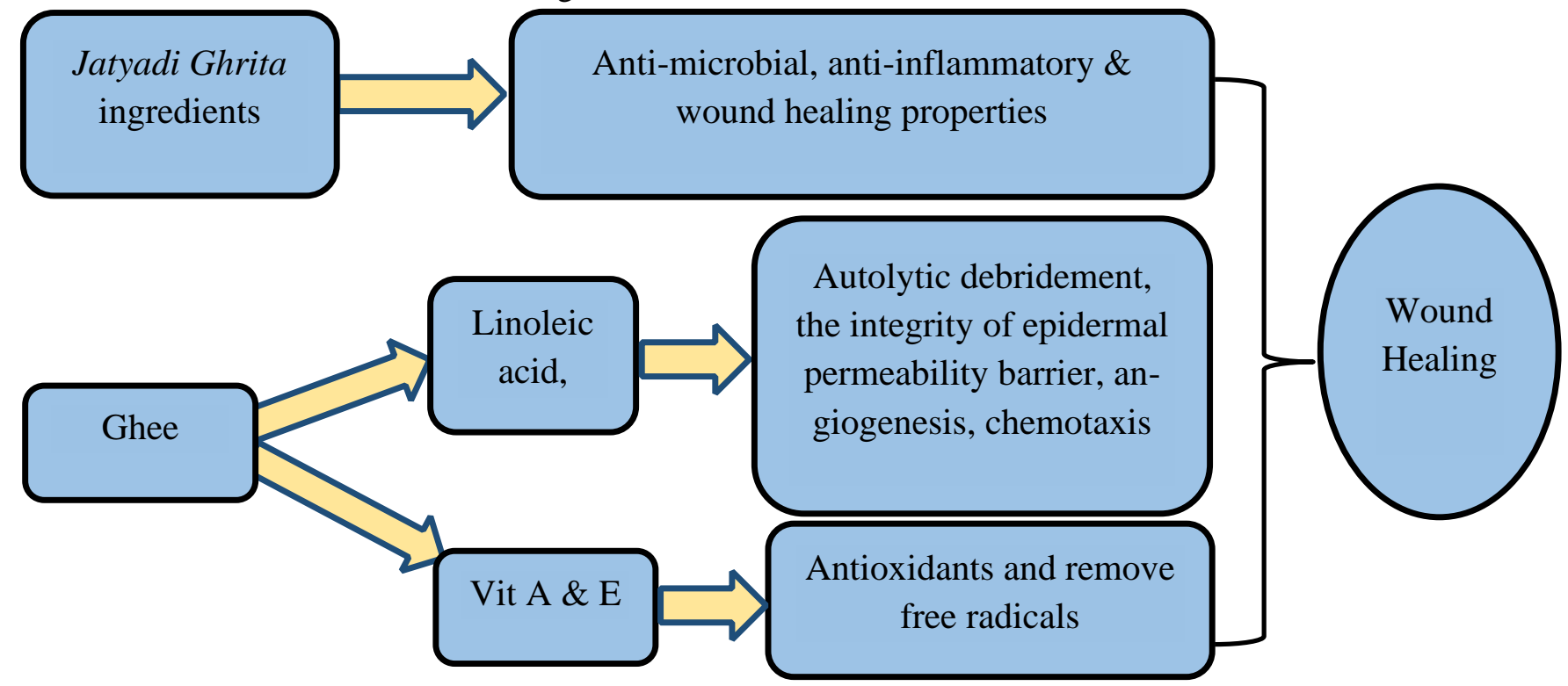

\section{CONCLUSION}

Management of chronic venous ulcers is tedious and time-consuming. Acharya Sushruta considering their difficult management has explained Shashti upakramas. Jatyadi Ghrita is one such medication, in which almost all the ingredients have Tikta katu rasa, Ushna veerya which helps in Shodhana of Vrana. It also has properties like Krimighna, Kandughna \& Kushtagnata. The chemical composition of ingredients consists of antimicrobial, antiseptic, antiinflammatory properties. Hence it is best for chronic non-healing ulcers. Keeping the drawbacks of conventional dressing in mind, sterilized, well packed Jatyadi Ghrita Vikeshika was prepared and used for topical application.

- In Group A: Relief from Pain was 69.23\%, Itching was $100 \%$, Foul smell was $95 \%$, Size reduction was $50 \%$, Relief from swelling was $100 \%$, Improvement in Margin was $73.80 \%$, Improvement in Floor was $73.46 \%$ and Reduction in Discharge was $63.15 \%$. 
- In Group B: Relief from Pain was $86.36 \%$, Itching was $100 \%$, Foul smell was $95 \%$, Size reduction was $33.33 \%$, Relief from swelling was $90 \%$, Improvement in Margin was $60 \%$, Improvement in Floor was $54 \%$ and Reduction in Discharge was $40.54 \%$.

- Overall relief in Group A is $78 \%$ and in Group B $70.5 \%$

- On observation, Sofratulle was found to be more effective in subsiding pain whereas Jatyadi ghrita Vikeshika was found more effective in reducing itching, swelling, foul smell, size of the ulcer, Margin \& floor of ulcer and discharge from the wound. Epithelialization and granulation tissue formation in Jatyadi Ghrita Vikeshika group was faster than the Sofratulle group. Hence Jatyadi Ghrita dressing is found to be more efficacious than Sofratulle Dressing in the management of Dushtavrana W.S.R. to Venous ulcer.

\section{REFERENCES}

1. Sriram Bhat M, SRB's Manual of Surgery, chapter 1, Jaypee Brothers Medical Publishers, New Delhi,2019 $6^{\text {th }}$ edition, $1 \mathrm{pp}$

2. Acharya Sushruta. Sushruta Samhita. (Nibhanda Sangraha commentary of Dalhana acharya\& Nyaya Panjika commentary of Gayadasa). Edited by Yadavji Trikamji, Sutrasthana,21 ${ }^{\text {st }}$ Chapter Chaukamba Sanskrit Samsthana, Varanasi; 2014, 1st ed., verse no.40, $107 \mathrm{pp}$

3. S. Das. A Concise Textbook of Surgery. Chapter $11,9^{\text {th }}$ Edition.2016,157pp.

4. https://www.ncbi.nlm.nih.gov $>A B C$ of wound healing: wound dressings.

5. Acharya Vagbhata. Ashtanga Hrudaya. (Sarvanga Sundari commentary of Shri Arunadatta\& Ayurveda Rasayana Commentary by Hemadri). Bhishagacharya Harish Shastri Paradakara Vaidya editor, Uttaratantra $25^{\text {th }}$ Chapter, Chaukamba Sanskrit Samsthana, Varanasi; $2017,10^{\text {th }}$ ed., Verse no.67-68,869pp.

6. https://www.ayujournal.org $>$ article

7. Acharya Sushruta. Sushruta Samhita. (Nibhanda Sangraha commentary of Dalhana acharya\& Nyaya Panjika commentary of Gayadasa). Edited by Yadavji Trikamji, Sutrasthana $18^{\text {th }}$ Chapter, Chaukamba San- skrit Samsthana, Varanasi; 2014, 1st ed. verse no. $3,84 \mathrm{pp}$

8. Acharya Sushruta. Sushruta Samhita. (Nibhanda Sangraha commentary of Dalhana acharya\& Nyaya Panjika commentary of Gayadasa). Edited by Yadavji Trikamji, Sutrasthana $18^{\text {th }}$ Chapter, Chaukamba Sanskrit Samsthana, Varanasi; 2014,1st ed. verse no.16,86pp

9. Acharya Sushruta. Sushruta Samhita. (Nibhanda Sangraha commentary of Dalhana acharya\& Nyaya Panjika commentary of Gayadasa). Edited by Yadavji Trikamji, Sutrasthana $18^{\text {th }}$ Chapter, Chaukamba Sanskrit Samsthana, Varanasi; 2014, 1st ed., verse no.17$18,87 \mathrm{pp}$

10. Acharya Sushruta. Sushruta Samhita. (Nibhanda Sangraha commentary of Dalhana acharya\& Nyaya Panjika commentary of Gayadasa). Edited by Yadavji Trikamji, Sutrasthana $18^{\text {th }}$ Chapter, Chaukamba Sanskrit Samsthana, Varanasi; 2014,1st ed., verse no.2126,88-89pp

11. Acharya Sushruta. Sushruta Samhita. (Nibhanda Sangraha commentary of Dalhana acharya\& Nyaya Panjika commentary of Gayadasa). Edited by Yadavji Trikamji, Sutrasthana, $18^{\text {th }}$ Chapter, Chaukamba Sanskrit Samsthana, Varanasi; 2014, 1st ed., verse no.2735,89pp

12. Acharya Charaka. Charaka Samhita. (Ayurveda Dipika Commentary of Chakrapani Datta, Edited by YadavjiTrikamji, Chiktisa sthana, $25^{\text {th }}$ chapter, Chaukamba Sanskrit Samsthana Varanasi;2013, 1st ed., verse no.95-96,596pp

13. Acharya Sushruta. Sushruta Samhita. (Nibhanda Sangraha commentary of Dalhana acharya\& Nyaya Panjika commentary of Gayadasa). Edited by Yadavji Trikamji, Sutrasthana $18^{\text {th }}$ Chapter, Chaukamba Sanskrit Samsthana, Varanasi; 2014, 1st ed., verse no. $3,84 \mathrm{pp}$

\section{Source of Support: Nil Conflict of Interest: None Declared}

How to cite this URL: Bhagyashree Parameshwar Hegde et al: A Clinical Study To Evaluate The Efficacy Of Jatyadi Ghrita Vikeshika Dressing In The Management Of Dushtavrana W.S.R. To Venous Ulcer. International Ayurvedic Medical Journal \{online\} 2021 \{cited November 2021\} Available from:

http://www.iamj.in/posts/images/upload/3186_3194.pdf 